\title{
PARTITIONING OF CHROMIUM, MANGANESE, COBALT AND NICKEL BETWEEN OLIVINE AND BASALTIC LIQUID: AN EXPERIMENTAL STUDY
}

\author{
HEIKKI T. MÄKIPÄÄ
}

\begin{abstract}
MÄKIPÄÄ, H. T. 1980: Partitioning of chromium, manganese, cobalt and nickel between olivine and basaltic liquid: an experimental study, Bull. Geol. Soc. Finland 52-2, 175-191.

The partitioning of $\mathrm{Cr}^{3+}, \mathrm{Mn}^{2+}, \mathrm{Co}^{2+}$ and $\mathrm{Ni}^{2+}$ between olivine and mafic silicate liquid has been studied under anhydrous conditions at 1 bar total pressure and temperatures of $1120^{\circ}$ to $1270^{\circ} \mathrm{C}$. The results suggest that 1) the partition coefficients for $\mathrm{Cr}, \mathrm{Mn}$, Co and $\mathrm{Ni}$ are strongly temperature dependent, 2) at constant temperature $\mathrm{D}_{\mathrm{Co}}$ is independent but $\mathrm{D}_{\mathrm{Cr}}, \mathrm{D}_{\mathrm{Mn}}$ and $\mathrm{D}_{\mathrm{Ni}}$ are dependent upon melt composition, 3) the partition cofficients are greater than one at these temperatrue ranges and the preference sequenc is $\mathrm{Ni}>$ $\mathrm{Co}>\mathrm{Mn}>\mathrm{Cr}, 4)$ the partition cofficients do not vary as a function of element content in the melt, 5) all partition coefficients can be used in geothermometry, the relative temperature accuracy being within $\pm 20^{\circ} \mathrm{C}$.

Heikki T. Mäkipää1, Nordic Volcanological Institute, University of Iceland, 101 Reykjavik, Iceland.
\end{abstract}

\section{Introduction}

The partitioning of trace elements between the common rock-forming minerals and liquid is interesting because of the petrogenetic history of melts. The partitioning depends of different parameters and may therefore, if properly calibrated, be used in geothermometry.

The transition metal partitioning is of particular interest because the elements are strongly concentrated in ferro-magnesian silicates. As a result of olivine and pyroxene fractionation the residual magma is rapidly depleted in the transition metals.

A number of papers have recently been

1 Present address: SN6, NASA, LBJ Space Center, Houston, Texas 77058, USA published on transition metal partitioning between olivine and silicate melt, especially that of nickel (e.g. Duke, 1976; Hart and Davis, 1978; Leeman and Lindstrom, 1978). Partition coefficients for cobalt have been determined by several workers, e.g. Leeman, (1974) and Duke (1976). Watson (1977) worked with Mn, and Schreiber and Haskin (1976) with Cr.

Some workers have assumed that trace element partition is independent of total composition, whereas others have emphasized the possibility of this relationship. The present account is an attempt to evaluate the compositional effect.

Many of the workers added spikes of the elements in question to the starting materials to get the experimental products 
Table 1. Composition of starting material.

\begin{tabular}{|c|c|c|c|c|c|c|c|c|c|}
\hline $\begin{array}{l}\text { Compo- } \\
\text { nents }\end{array}$ & No & $\mathrm{N}-503^{1}$ & TH-102 & $\mathrm{K}-731^{1}$ & $\mathrm{RE}-5^{2}$ & $\mathrm{~N}-216^{3}$ & NAL-134 & $\mathrm{HE}-30^{2}$ & $\mathrm{HE}-35^{2}$ \\
\hline $\mathrm{SiO}_{2}$ & & 50.25 & 49.26 & 49.93 & 48.98 & 47.5 & 47.60 & 50.22 & 50.22 \\
\hline $\mathrm{TiO}_{2}$ & & 2.13 & 1.34 & 1.70 & 1.63 & 0.75 & 1.09 & 1.07 & 0.97 \\
\hline $\mathrm{Al}_{2} \mathrm{O}_{3}$ & & 13.42 & 14.24 & 13.83 & 14.93 & 15.8 & 16.66 & 14.47 & 15.19 \\
\hline $\mathrm{Fe}_{2} \mathrm{O}_{3}$ & & 4.15 & 2.20 & 2.54 & 2.49 & 0.74 & 0.88 & 1.15 & 1.13 \\
\hline $\mathrm{FeO}$ & & 11.14 & 9.87 & 9.98 & 9.90 & 8.51 & 8.77 & 9.98 & 9.99 \\
\hline $\mathrm{MnO}$ & & 0.24 & 0.19 & 0.22 & 0.20 & 0.16 & 0.13 & 0.18 & 0.19 \\
\hline $\mathrm{MgO}$ & & 5.43 & 7.09 & 7.23 & 7.39 & 9.8 & 9.56 & 10.23 & 10.50 \\
\hline $\mathrm{CaO}$ & & 10.30 & 10.66 & 11.63 & 11.38 & 13.2 & 12.76 & 10.15 & 10.60 \\
\hline $\mathrm{Na}_{2} \mathrm{O}$ & & 2.38 & 1.99 & 2.20 & 2.39 & 1.7 & 2.14 & 1.26 & 1.41 \\
\hline $\mathrm{K}_{2} \mathrm{O}$ & & 0.33 & 0.18 & 0.26 & 0.20 & 0.09 & 0.11 & 0.10 & 0.10 \\
\hline $\mathrm{P}_{2} \mathrm{O}_{5}$ & & 0.23 & 0.19 & 0.11 & 0.19 & - & 0.09 & 0.09 & 0.08 \\
\hline Total & & 100.00 & 97.21 & 99.63 & 99.68 & 98.23 & 99.79 & 98.90 & 100.38 \\
\hline
\end{tabular}

\begin{tabular}{lllll}
\hline Comp. No. & 5 & 6 & 7 & 8 \\
\hline
\end{tabular}

1 Grönvold and Mäkipää (1978)

2 Mäkipää (1978 a)

3 Unpublished XRF analysis by Dr. K. Grönvold

within the analytical range of the microprobe. It is, however, questionable whether Henry's law is valid at higher concentrations. Some workers have avoided the issue by using beta-track mapping, which can be used at lower concentrations.

In many common basaltic rocks the transition metal concentration, particularly that of $\mathrm{Cr}, \mathrm{Mn}$ and also $\mathrm{Ni}$, exceeds the present analytical limit of the microprobe $(40 \mathrm{ppm} \pm$ $5 \mathrm{ppm})$. With such rocks it is possible to work with realistic compositions experimentally; the behaviour at lower concentrations is then less important.

In the present study the olivine/liquid partition coefficients for $\mathrm{Cr}, \mathrm{Mn}$, Co and $\mathrm{Ni}$ in basaltic systems were determined experimentally. The bulk composition of the glasses used as starting materials (before doping) are given in Table 1. Two of them are lavas from the 1975 and 1977 eruptions in northern Iceland (Grönvold and Mäkipää, 1978), four are older pleistocene tholeiites (Mäkipää, 1978 a) and two more MgO-rich lavas from northern Iceland. The composition varies from quartz normative to olivine normative tholeiites. The temperature varied

\author{
4 Mäkipää (1978 b) \\ $\mathrm{Fe}_{2} \mathrm{O}_{3} / \mathrm{FeO}$ calculation Mäkipää (1979) \\ - not determined
}

from $1270^{\circ}$ to $1100{ }^{\circ} \mathrm{C}$ at atmospheric pressure and the oxygen fugacity from $10^{-6}$ to $10^{-10}$. The validity of Henry's law at higher concentrations $(\sim 1 \%)$ is demonstrated.

\section{Experimental procedures}

\section{Analytical methods}

In phase-equilibrium studies the most important problems of major elements are associated with the determination of thermodynamic activities. For trace elements expected to obey dilute solution laws the major problem is the limitation of existing analytical techniques (Drake, 1972).

Techniques such as neutron activation, isotope dilution, X-ray fluorescence and others, which permit the high-precision analysis of elements present in trace amounts, suffer from the serious limitation that they do not permit the phases in situ in the sample to be analysed. This problem is avoided by using an electron microprobe X-ray analyzer. Major elements are easily analysed, but trace elements are somewhat problematic. The detection limits vary, depending on the element 
and the matrix, but a 100-ppm detection limit is typical; using special operating conditions, however, substantially lower levels can be reached.

The mineral and glass analyses were all carried out on an automatic ARL-SEMQ microprobe. The major elements were analysed by operating the electron probe at an accelerating voltage of $15 \mathrm{kV}$ and a sample current of $25 \mathrm{nA}$. The counting time was 20 seconds on peak and 4 seconds on background.

The trace elements were analysed using a $25-\mathrm{kV}$ accelerating voltage and a $0.6-\mu \mathrm{A}$ sample current. The counting times were usually 100 seconds on peak and 40 seconds on background.

During the measurements, changes in the line position, shape and relative intensity of the X-ray spectra were observed. The wavelength shift is strongest for the light element $\mathrm{K}$-lines. The $\mathrm{K}$-line peak shifts are often rather large and must therefore be taken into account (Häkli 1963). Hence, the trace elements were determined under special conditions, and the line position was checked for each element. The standards employed for the various elements were: augite and hornblende for all transition metals in low concentrations; synthetic chalcopyrite for $\mathrm{Ni}$ and $\mathrm{Co}(1 \% \mathrm{Ni}, 1 \% \mathrm{Co})$ and rhodonite for Mn. In addition a glass standard with $\mathrm{Co}$ and
Ni spike was used. To test the accuracy of analyses a number of spot analyses were performed on the doped materials. So far the results indicate that all the analyses discussed here can be used quantitatively.

\section{Experimental techniques}

The experiments were conducted in a Ptwound vertical quench furnace at the University of Iceland. The run temperatures were measured using a $\mathrm{Pt} / \mathrm{Pt}-10 \%-\mathrm{Rh}$ thermocouple before and after each run. The thermocouple was calibrated at the melting point of gold $\left(1064.4{ }^{\circ} \mathrm{C}\right)$. The temperature fluctuation during each run was within $1{ }^{\circ} \mathrm{C}$; thus the reported temperatures are considered to be accurate to $\pm 2{ }^{\circ} \mathrm{C}$ or better.

The runs were made at atmospheric pressure. The $\mathrm{fo}_{2}$ in the furnace was controlled by a mixture of carbon dioxide and hydrogen passed upwards through the furnace at a constant rate $(\sim 4 \mathrm{cc} / \mathrm{s})$.

Glasses were produced by heating the samples for about 20 minutes at $1320{ }^{\circ} \mathrm{C}$ and then suspending them directly into the furnace at the desired temperature. This procedure has been found to produce the most homogeneous and euhedral crystals. The samples were held in a pure Pt loop in the hottest zone of the furnace, where no tem-
Fig. 1. Ni partitioning between olivine and liquid at constant temperature (1206 ${ }^{\circ}$ C) as a function of run duration showing the run duration required to the equilibrium. The individual dots with the same run duration indicate different $\mathrm{Ni}$ concentrations in sample.

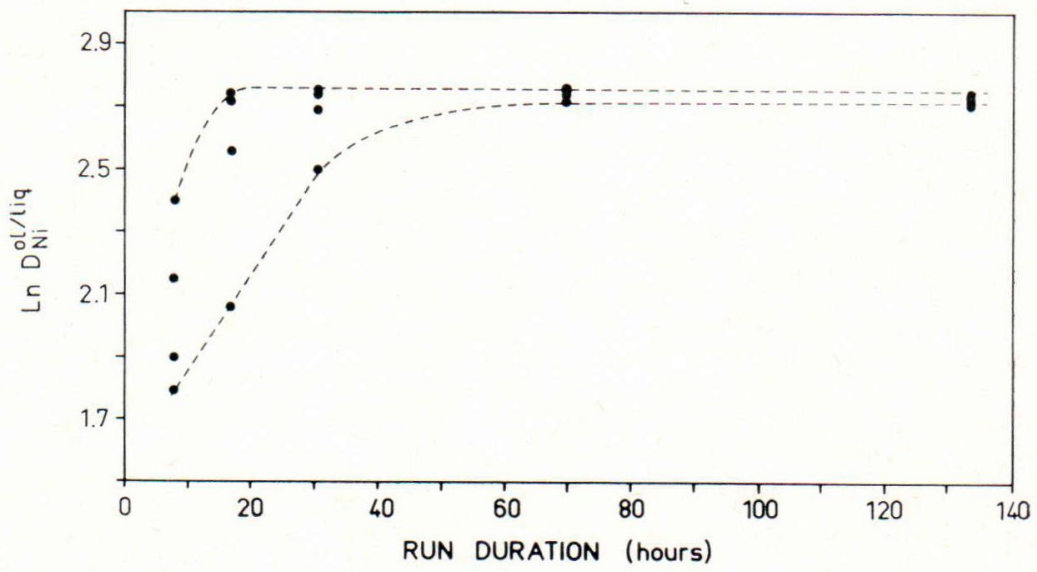




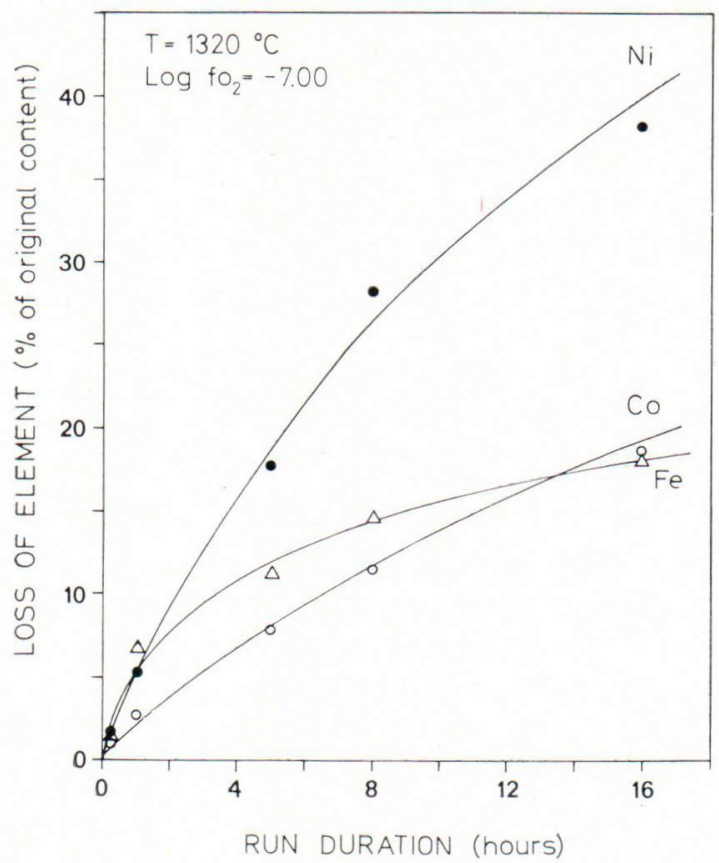

Fig. 2. Loss of elements during the run as a function of run duration using unsaturated platinum wires as containers.

perature gradient was detectable for a length of $4 \mathrm{~cm}$.

Major element equilibrium can be attained with a run duration of 24 hours (e.g. Duke, 1976). This time may, however, be substantially too low for trace element equilibration. The attainment of trace element equilibrium depends on run duration, the element in question and the temperature. These parameters were established by a number of experiments.

The runs at constant temperature with different durations (Fig. 1) indicate that the equilibrium partitioning of $\mathrm{Ni}$ between olivine and liquid requires a run lasting at least 30 hours. Shorter runs suffice to attain equilibrium partitioning of $\mathrm{Cr}$ and $\mathrm{Mn}$ between olivine and liquid. These results agree well with the experiments of Leeman and Lindstrom (1978).

It must be pointed out, however, that at lower temperatures $\left(1100^{\circ}-1150^{\circ} \mathrm{C}\right)$ the run must last much longer $(>70 \mathrm{~h})$ before the trace elements equilibrate.

Drake (1972) reported that about $30 \%$ of all the experimental-run products are lost owing to kinetic problems during the attainment of equilibrium between plagioclase and liquid. To avoid this with olivine some duplicate experiments were performed without any significant gain. Note that all the D values reported here are based on at least two separate experiments.

\section{Oxidation state and oxygen fugacity during the runs}

Each of the transition metals can occur in at least two different oxidation states. The relative amount in the various oxidation states depends mainly on oxygen fugacity and temperature and is also influenced by bulk composition (Duke, 1976).

Under natural conditions $\mathrm{Co}, \mathrm{Ni}$ and $\mathrm{Mn}$ (Watson, 1977) appear to be dominantly in the divalent state, whereas $\mathrm{Cr}$ is in the trivalent state.

In most of the runs the oxygen fugacity was kept close to the FMQ-buffer, in accordance with the FMQ-buffer equation of Wones and Gilbert (1969):

$\log \mathrm{fo}_{2}=-25738 / \mathrm{T}\left({ }^{\circ} \mathrm{K}\right)+9.00$

The composition of the gas mixture at a given temperature was calibrated by $\mathrm{Mr}$. Sigurdur Jakobsson using the $\mathrm{O}_{2}$ probe. The reported oxygen fugacities are accurate to within $\pm 0.2 \log$ units or better.

The FMQ-buffer gives a slightly more oxidizing atmosphere than the $\mathrm{Co}-\mathrm{CoO}$ buffer, so that Co was in the divalent state in all the experiments.

To ensure that $\mathrm{NiO}$ is not significantly reduced some of the runs were conducted at an oxygen fugacity that was slightly more oxidizing than the $\mathrm{Ni}-\mathrm{NiO}$ buffer. In this oxygen fugacity range $\mathrm{Mn}$ is always in the 
divalent state and $\mathrm{Cr}$ in the trivalent state (Watson, 1977).

However, according to Schreiber and Haskin (1976), some $\mathrm{Cr}$ might be in the divalent state at these oxygen fugacities. Thus $\mathrm{Mn}, \mathrm{Co}$ and $\mathrm{Ni}$ were in the divalent state and $\mathrm{Cr}$ predominantly in the trivalent state in all the present experiments.

The Pt wire loops used in the experiments should give the best oxygen fugacity control, because with them the samples are completely exposed to the gas mixture.

\section{Loss of elements during runs}

Some of the iron in a sample is absorbed by the platinum container. The same would be expected for $\mathrm{Ni}$ and $\mathrm{Co}$, too. At an early stage the iron loss was believed to be »not extensive enough to change results significantly and destroy the normative chemistry of basalts» (e.g. Green and Ringwood, 1967). Mysen et al. (1975) reported that with $\mathrm{Pt}_{95} \mathrm{Au}_{5}$ capsules the iron loss to the container was considerably lower than with pure Pt capsules.

However, according to Johannes an Bode (1978), the loss of iron from basalts to $\mathrm{Pt}$ capsules is highly significant and increases with increasing temperature, run duration and hydrogen fugacity. Further, they pointed out that $\mathrm{Pt}_{95} \mathrm{Au}_{5}$ containers do not eliminate the drawback. They reported about $40-70 \%$ loss of iron at $1200{ }^{\circ} \mathrm{C}$ even in 8-hour runs.

Platinum wire loops can be used in experiments at one-atm pressure, and the loss of the elements is less significant. To minimize the element loss in the present experiments the weight ratio $\mathrm{Pt} / \mathrm{basalt}$ was kept as low as possible. The average Pt-wire/ basalt weight ratio in the experiments was 1:8 compared with the Pt-capsule/basalt weight ratio $4: 1$.

To establish the extent of $\mathrm{Fe}, \mathrm{Co}$ and $\mathrm{Ni}$ loss to the container some experiments were conducted at different run durations, oxygen fugacities and temperatures. At high temperature the run duration is the most serious factor in removing elements from the liquid. As shown in Fig. 2, the loss of $\mathrm{Ni}$ is up to about $40 \%$ during a 16 -hour run. In experiments performed with very $\mathrm{MgO}$-rich magmas the samples lose a highly significant amount of their original transition metal contents during the runs (which usually last for several days). The loss of the elements decreases rapidly with decreasing temperature and at $1200{ }^{\circ} \mathrm{C}$ the loss of $\mathrm{Ni}$ is about $10 \%$ within 7 days.

The loss of iron is noticeable, especially at higher temperatures, though it is not so significant as reported by Johannes and Bode (1978). At $1200{ }^{\circ} \mathrm{C}$ the loss is only a few percentages of the starting compositions. The loss of iron and other elements can be reduced by presaturating the $\mathrm{Pt}$ wire with the same material for several hours at high temperature. After presaturation of 170 hours at $1250{ }^{\circ} \mathrm{C}$ the loss of all elements (except alkalies) is insignificant.

\section{Run products and the homogeneity} of the phases

The samples were quenched either by dropping them into water or by pulling them rapidly out of the furnace. The absence of any overgrowth or quench crystals suggests rapid quenching.

The glasses produced were very homogeneous and contained varying amounts of olivine and plagioclase as the primary liquidus phases. The maximum degree of crystallization was visually estimated to be less than $20 \%$ and to contain both olivine and plagioclase.

The olivines were usually small euhedral crystals (Fig. 3). Subhedral or skeletal olivine were rare. Some olivines occasionally contained small chromium spinels. 


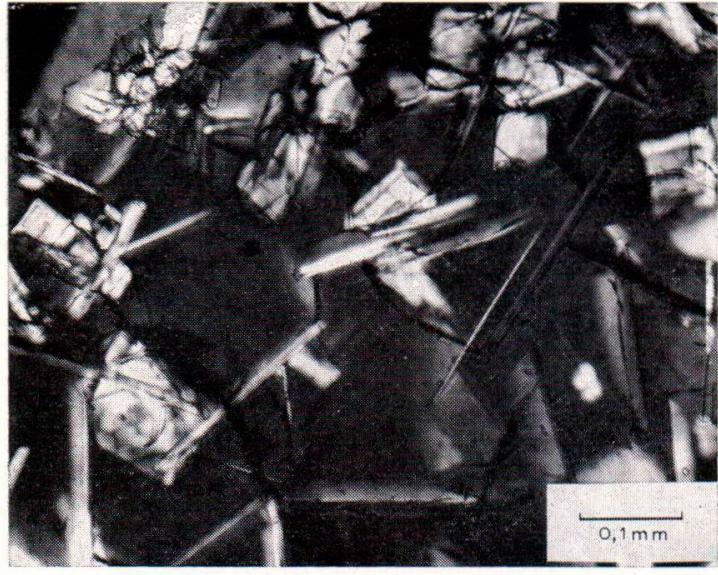

Fig. 3. Run product (KRA 731/16) showing the morphology of plagioclase and olivine crystals. $\mathrm{T}=1162{ }^{\circ} \mathrm{C}, \quad \log$ fo $_{2}=-9.06$, run duration 25 hours.

In all experiments plagioclase was the second or first crystallization phase and the crystals were usually euhedral laths (Fig. 3). Sometimes, however, they also showed swallow-tailed morphology, especially after short runs. At high oxygen fugacities chromiumspinel crystallization played an important role. In some cases the spinel was the first phase to appear and formed large octahedral crystals.

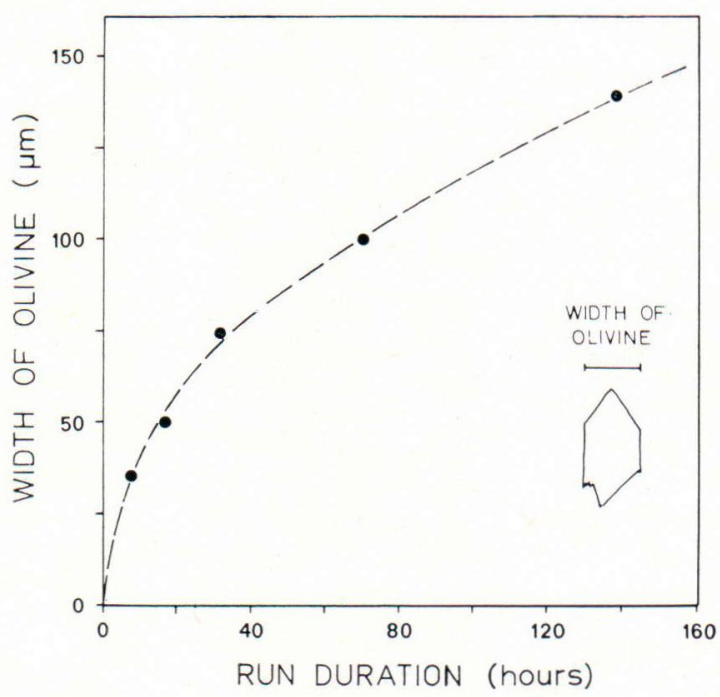

Fig. 4. The growth of olivine crystal in experiment as a function of run duration.
The size of the olivine crystals correlates well with the run duration (Fig. 4). Some workers have reported difficulties, especially at higher pressures, to get crystals large enough for microprobe analysis. The problem is not so serious in experiments at 1-atm pressure because even during the 8-hour runs the crystals reached the size required.

The equilibrium partitioning of $\mathrm{Fe}, \mathrm{Co}$ and $\mathrm{Ni}$ was studied as a function of run duration by approaching the equilibrium from two directions.

First, both samples were melted for about ten minutes at $1320{ }^{\circ} \mathrm{C}$. One glassy sample was suspended directly at the desired temperature $\left(1200{ }^{\circ} \mathrm{C}\right)$ and equilibrated for 8 and 40 hours. Another sample was first equilibrated for 30 hours at $1150{ }^{\circ} \mathrm{C}$ and then reequilibrated for 8 and 40 hours at $1200{ }^{\circ} \mathrm{C}$. The results clearly reveal that although reequilibration takes much longer, after 40 hours the results are identical.

This test indicates that the partition data reported here well represent the equilibrium values.

\section{Results}

\section{Henry's law behaviour}

$\mathrm{Ni}$ partitioning in olivine appears to follow Henry's law over a range from $0.1 \%$ to at least $5 \% \mathrm{NiO}$ (Hart and Davis, 1978). In contrast, Mysen (1978) reported very large changes in partition coefficients as a function of $\mathrm{Ni}$ content.

To test the feasibility of Henry's law at higher concentrations $\mathrm{CoO}$ and $\mathrm{NiO}$ were added as oxides to a selected sample in the following concentrations (ppm): 200 to 11000 for $\mathrm{Co}$, and 300 to 12000 for Ni.

Natural concentrations $50-290 \mathrm{ppm} \mathrm{Cr}$ and $1450-2230 \mathrm{ppm} \mathrm{Mn}$ were used.

The results (Fig. 5) indicate that the parti- 


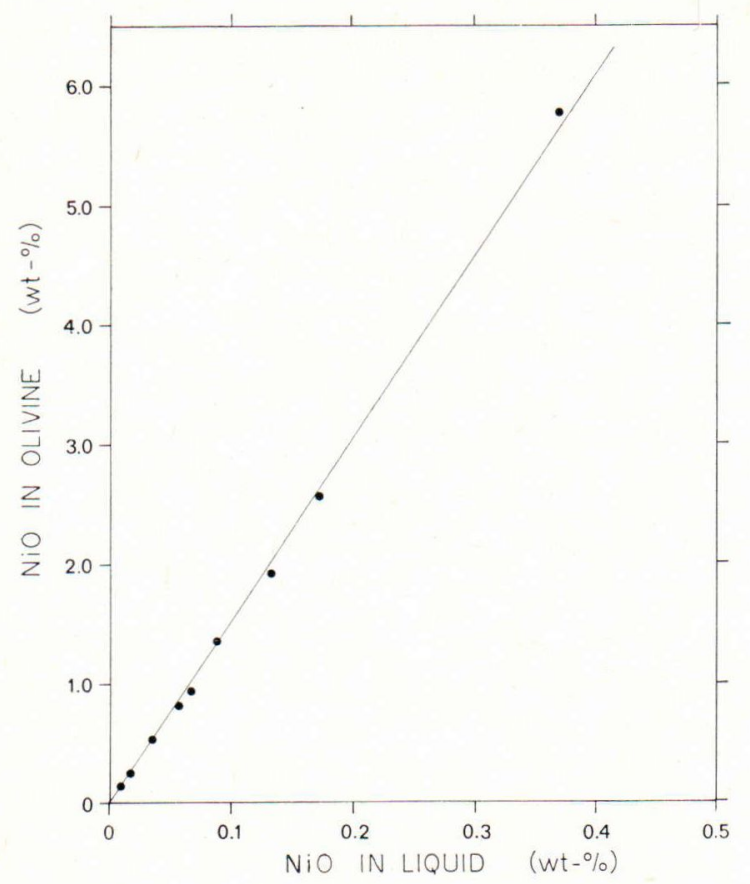

Fig. 5. The Henry's law behaviour for Ni.

tion coefficient for $\mathrm{Ni}$ does not vary as a function of the element content of the melt, i.e. it obeys Henry's law.

\section{Partition coefficients}

The partition coefficients are here defined as

$$
\mathrm{D}_{i}^{\mathrm{ol} / \mathrm{liq}}=\frac{\mathrm{C} \underset{\mathrm{i}}{\mathrm{ol}}}{\mathrm{C}_{i}^{\mathrm{liq}}}
$$

where $\mathrm{C} \underset{\mathrm{i}}{\mathrm{ol}}$ is the concentration of element $\mathrm{i}$ $(\mathrm{ppm})$ in olivine and $\mathrm{C} \underset{\mathrm{i}}{\operatorname{liq}}$ in liquid.

A summary of run conditions and the averaged $\mathrm{Cr}, \mathrm{Mn}$, Co and $\mathrm{Ni}$ partition coefficients are given in Table 2.

Dependence of $D$ on oxygen fugacity, temperature and composition

\section{Chromium}

The data available for $\mathrm{Cr}$ partitioning as a function of oxygen fugacity are very limited. Huebner and Lipin (1976) reported that the partition of chromium between olivine and silicate liquid is independent of the redox state, temperature and $\mathrm{Mg} /(\mathrm{Mg}+\mathrm{Fe})$. They did find out, however, that $\mathrm{D}_{\mathrm{Cr}}$ tends to increase with decreasing oxygen fugacity.
Fig. 6. The partitioning of $\mathrm{Cr}$ between olivine and liquid as a function of temperature. L \& S - Leeman \& Scheidegger (1977), D Duke (1976), open circles test samples (natural lava).

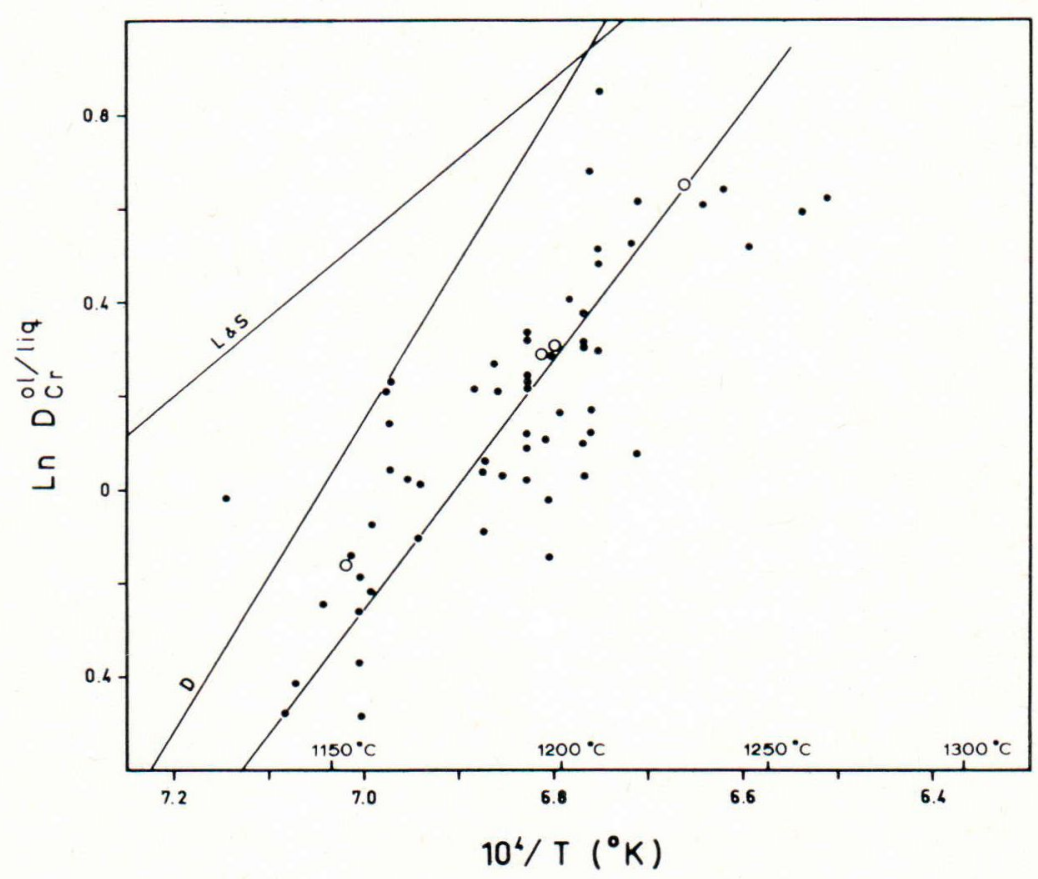


Table 2. Experimental conditions and results.

\begin{tabular}{|c|c|c|c|c|c|c|c|c|c|c|c|c|}
\hline Run No. & Comp. & $\mathrm{T}\left({ }^{\circ} \mathrm{C}\right)$ & $\log \mathrm{fo}_{2}$ & $\begin{array}{l}\text { Run } \\
\text { duration } \\
\text { (hours) }\end{array}$ & $\mathrm{D}_{\mathrm{Cr}}$ & $\mathrm{Cr}$ & $\mathrm{D}_{M n}$ & $\mathrm{Mn}$ & $\mathrm{D}_{\mathrm{Co}}$ & Co & $\mathrm{D}_{\mathrm{Ni}}$ & $\mathrm{Ni}$ \\
\hline 11 & 5 & 1125 & - & 64 & 0.97 & 123 & 1.46 & 1670 & 5.05 & 90 & 18.82 & 96 \\
\hline 2 & 6 & 1198 & -8.3 & 24 & 1.32 & 200 & 1.42 & 2009 & 2.94 & 82 & 15.25 & 128 \\
\hline 3 & 6 & 1155 & -8.5 & 48 & 0.69 & 220 & 1.50 & 1899 & 4.90 & 62 & 18.59 & 91 \\
\hline 4 & 7 & 1192 & -8.9 & 23 & 1.24 & 290 & 1.26 & 2010 & 3.28 & 390 & 16.96 & 125 \\
\hline 5 & 7 & 1187 & -8.7 & 24 & 1.03 & 286 & 1.35 & 1981 & 3.85 & 393 & 16.96 & 90 \\
\hline 6 & 7 & 1186 & -9.0 & 23 & 1.23 & 188 & 1.47 & 1862 & 3.78 & 478 & 16.67 & 81 \\
\hline 7 & 7 & 1183 & -8.8 & 42 & 1.06 & 228 & 1.41 & 1821 & 3.88 & 444 & 16.82 & 92 \\
\hline 8 & 7 & 1180 & -9.1 & 23 & 1.23 & 184 & 1.34 & 2085 & 3.59 & 380 & 17.60 & 125 \\
\hline 9 & 7 & 1168 & -8.9 & 21 & 0.90 & 221 & 1.47 & 1861 & 4.01 & 480 & 17.40 & 98 \\
\hline 10 & 7 & 1166 & -9.3 & 24 & 1.02 & 188 & 1.41 & 1816 & 4.59 & 407 & 19.62 & 104 \\
\hline 11 & 7 & 1162 & -9.1 & 25 & 1.05 & 271 & 1.62 & 1671 & 3.87 & 420 & 19.74 & 86 \\
\hline 12 & 7 & 1161 & -9.3 & 24 & 1.23 & 175 & 1.35 & 1690 & 3.75 & 360 & 18.38 & 80 \\
\hline 13 & 7 & 1158 & -9.0 & 24 & 0.80 & 269 & 1.52 & 1772 & 4.66 & 480 & 19.91 & 96 \\
\hline 14 & 7 & 1155 & -8.6 & 24 & 0.61 & 184 & 1.54 & 1810 & 4.53 & 420 & 18.71 & 77 \\
\hline $15^{2}$ & 7 & 1153 & -9.1 & 22 & 0.87 & 262 & 1.68 & 1587 & 3.89 & 497 & 16.62 & 89 \\
\hline $16^{2}$ & 7 & 1147 & -9.3 & 22 & 0.78 & 261 & 1.73 & 1508 & 4.22 & 448 & 16.88 & 105 \\
\hline $17^{2}$ & 7 & 1142 & -9.5 & 32 & 0.66 & 224 & 1.35 & 1507 & 4.34 & 445 & 18.92 & 99 \\
\hline 18 & 7 & 1140 & -9.6 & 67 & 0.62 & 151 & 1.59 & 1636 & 5.13 & 420 & 22.63 & 95 \\
\hline 19 & 8 & 1185 & -8.4 & 24 & 1.31 & 251 & 1.43 & 2102 & 3.41 & 69 & 15.15 & 93 \\
\hline 20 & 8 & 1155 & -8.5 & 48 & 0.83 & 235 & 1.46 & 2062 & 4.82 & 60 & 19.63 & 80 \\
\hline 21 & 9 & 1234 & -8.1 & 26 & 1.83 & 375 & 1.09 & 1490 & 2.59 & 301 & 11.82 & 162 \\
\hline 22 & 9 & 1218 & -8.4 & 44 & 1.85 & 360 & 1.15 & 1459 & 2.75 & 209 & 13.55 & 143 \\
\hline 23 & 9 & 1217 & -8.2 & 28 & 1.08 & 362 & 1.12 & 1438 & 3.02 & 231 & 12.94 & 120 \\
\hline 24 & 9 & 1202 & -8.5 & 49 & 1.50 & 358 & 1.15 & 1470 & 3.30 & 269 & 14.63 & 125 \\
\hline $25^{1}$ & 10 & 1263 & -7.8 & 38 & 1.86 & 332 & 1.09 & 1446 & 2.4 .2 & 125 & 11.00 & 198 \\
\hline $26^{1,2}$ & 10 & 1258 & -7.9 & 9 & 1.81 & 340 & 1.21 & 1420 & 2.06 & 180 & 8.81 & 200 \\
\hline $27^{1}$ & 10 & 1244 & -8.1 & 15 & 1.69 & 388 & 1.11 & 1506 & 2.90 & 148 & 12.22 & 125 \\
\hline 28 & 10 & 1198 & -8.5 & 48 & 0.86 & 160 & 1.29 & 1450 & 3.20 & 177 & 16.63 & 111 \\
\hline 29 & 10 & 1197 & -9.5 & 120 & 1.11 & 150 & 1.25 & 1631 & 3.40 & 182 & 15.35 & 134 \\
\hline 30 & 11 & 1238 & -7.8 & 24 & 1.90 & 260 & 1.22 & 1621 & 2.41 & 107 & 12.62 & 211 \\
\hline 31 & 12 & 1216 & -8.0 & 24 & 1.69 & 321 & 1.31 & 1741 & 2.78 & 97 & 13.60 & 180 \\
\hline 32 & 12 & 1208 & -7.9 & 137 & 1.69 & 158 & 1.14 & 1610 & 3.03 & 139 & 15.59 & 3709 \\
\hline 33 & 12 & 1208 & -7.9 & 137 & 2.33 & 151 & 1.16 & 1680 & 2.94 & 141 & 15.03 & 1715 \\
\hline 34 & 12 & 1208 & -7.9 & 137 & - & - & 1.14 & 1585 & 2.64 & 154 & 14.61 & 1319 \\
\hline 35 & 12 & 1208 & -7.3 & 137 & 1.34 & 160 & 1.22 & 1599 & 3.17 & 144 & 15.78 & 867 \\
\hline 36 & 12 & 1208 & -7.9 & 137 & - & - & 1.12 & 1551 & 2.91 & 156 & 14.78 & 676 \\
\hline 37 & 12 & 1208 & -7.9 & 137 & - & - & 1.23 & 1519 & 2.90 & 157 & 14.85 & 548 \\
\hline 38 & 12 & 1208 & -7.9 & 137 & 1.62 & 94 & 1.17 & 1578 & 2.80 & 191 & 15.61 & 341 \\
\hline $39^{2}$ & 12 & 1207 & -7.9 & 17 & 1.28 & 78 & 1.10 & 1569 & 3.11 & 128 & 15.52 & 3670 \\
\hline $40^{2}$ & 12 & 1207 & -7.9 & 17 & 0.76 & 80 & 1.01 & 1578 & 2.77 & 150 & 15.49 & 1660 \\
\hline $41^{2}$ & 12 & 1207 & -7.9 & 17 & 0.97 & 81 & 1.01 & 1562 & 2.47 & 146 & 14.32 & 1220 \\
\hline 422 & 12 & 1207 & -7.9 & 17 & 1.01 & 92 & 0.99 & 1520 & 2.36 & 160 & 13.82 & 812 \\
\hline $43^{2}$ & 12 & 1207 & -7.9 & 17 & - & - & 1.03 & 1530 & 2.35 & 150 & 12.99 & 627 \\
\hline $44^{2}$ & 12 & 1207 & -7.9 & 17 & - & - & 1.01 & 1560 & 2.20 & 122 & 10.12 & 483 \\
\hline $45^{2}$ & 12 & 1207 & -7.9 & 17 & 1.38 & 109 & 1.04 & 1559 & 2.08 & 150 & 7.86 & 121 \\
\hline $46^{2}$ & 12 & 1206 & -7.9 & 8 & 0.65 & 113 & 0.99 & 1648 & 1.75 & 231 & 11.04 & 4540 \\
\hline
\end{tabular}




\begin{tabular}{|c|c|c|c|c|c|c|c|c|c|c|c|c|}
\hline 472 & 12 & 1206 & -7.9 & 8 & 0.91 & 110 & 0.99 & 1653 & 2.05 & 247 & 8.56 & 2918 \\
\hline $48^{2}$ & 12 & 1206 & -7.9 & 8 & - & - & 0.90 & 1612 & 2.10 & 259 & 7.22 & 1403 \\
\hline 492 & 12 & 1206 & -7.9 & 8 & - & - & 1.01 & 1630 & 2.22 & 248 & 6.40 & 864 \\
\hline $50^{2}$ & 12 & 1206 & -7.9 & 8 & 0.56 & 73 & 0.95 & 1676 & 2.06 & 280 & 6.56 & 422 \\
\hline 512 & 12 & 1206 & -7.9 & 8 & 2.32 & 106 & 1.05 & 1616 & 2.19 & 181 & 6.01 & 425 \\
\hline $52^{2}$ & 12 & 1206 & -7.9 & 8 & - & - & 1.05 & 1636 & 2.20 & 160 & 5.92 & 208 \\
\hline 53 & 12 & 1206 & -7.9 & 31 & - & - & 1.04 & 1612 & 2.51 & 221 & 15.62 & 5207 \\
\hline 54 & 12 & 1206 & -7.9 & 31 & - & - & 1.07 & 1716 & 2.51 & 199 & 14.76 & 2434 \\
\hline 55 & 12 & 1206 & -7.9 & 31 & - & - & 1.04 & 1698 & 2.94 & 178 & 15.40 & 1801 \\
\hline 56 & 12 & 1206 & -7.9 & 31 & - & - & 1.08 & 1712 & 2.62 & 210 & 14.17 & 1648 \\
\hline 57 & 12 & 1206 & -7.9 & 31 & - & - & 1.10 & 1744 & 2.87 & 171 & 12.16 & 1075 \\
\hline 58 & 12 & 1206 & -7.9 & 31 & - & - & 1.02 & 1790 & 2.77 & 241 & 12.92 & 898 \\
\hline 59 & 12 & 1206 & -7.0 & 31 & - & - & 1.01 & 1860 & 2.81 & 252 & 11.71 & 411 \\
\hline 60 & 12 & 1206 & -8.3 & 41 & 1.97 & 117 & 1.14 & 1635 & 2.80 & 517 & 14.61 & 1040 \\
\hline 61 & 12 & 1206 & -8.3 & 41 & 1.18 & 184 & 1.08 & 1584 & 2.86 & 139 & 15.01 & 1115 \\
\hline 62 & 12 & 1206 & -8.3 & 41 & 1.13 & 186 & 1.10 & 1562 & 3.07 & 6297 & 15.46 & 94 \\
\hline 63 & 12 & 1205 & -8.0 & 70 & - & - & 1.15 & 1585 & 3.23 & 242 & 15.07 & 3080 \\
\hline 64 & 12 & 1205 & -8.0 & 70 & - & - & 1.12 & 1518 & 3.53 & 163 & 15.95 & 1207 \\
\hline 65 & 12 & 1205 & -8.0 & 70 & 1.37 & 183 & 1.17 & 1545 & 3.10 & 205 & 15.58 & 1029 \\
\hline 66 & 12 & 1205 & -8.0 & 70 & 1.10 & 180 & 1.18 & 1589 & 3.14 & 109 & 15.97 & 621 \\
\hline 67 & 12 & 1205 & -8.0 & 70 & - & - & 1.22 & 1540 & 3.33 & 146 & 15.20 & 486 \\
\hline 68 & 12 & 1205 & -8.0 & 70 & 1.35 & 169 & 1.10 & 1521 & 3.23 & 132 & 14.90 & 412 \\
\hline 69 & 12 & 1205 & -8.0 & 70 & - & - & 1.19 & 1527 & 3.40 & 102 & 15.00 & 188 \\
\hline 70 & 12 & 1205 & -8.0 & 87 & 1.03 & 71 & 1.26 & 1506 & 3.62 & 19611 & 16.10 & 180 \\
\hline 71 & 12 & 1205 & -8.0 & 87 & - & - & 1.17 & 1552 & 3.82 & 7170 & 15.54 & 193 \\
\hline 72 & 12 & 1205 & -8.0 & 87 & - & - & 1.30 & 1569 & 3.40 & 5200 & 16.35 & 170 \\
\hline 73 & 12 & 1205 & -8.0 & 87 & - & - & 1.29 & 1561 & 3.73 & 3038 & 15.49 & 191 \\
\hline 74 & 12 & 1205 & -8.0 & 87 & $\overline{1 a}$ & $\overline{7}$ & 1.16 & 1480 & 3.55 & 1943 & 15.30 & 171 \\
\hline 75 & 12 & 1205 & -8.0 & 87 & 1.46 & 74 & 1.26 & 1433 & 3.52 & 875 & 15.57 & 180 \\
\hline 76 & 12 & 1200 & -8.5 & 69 & 1.18 & 343 & 1.18 & 1623 & 3.50 & 102 & 16.09 & 160 \\
\hline 77 & 12 & 1197 & -8.5 & 45 & 0.98 & 349 & 1.25 & 1760 & 3.80 & 5129 & 16.30 & 547 \\
\hline 78 & 12 & 1192 & -9.4 & 58 & 1.27 & 270 & 1.30 & 1860 & 4.17 & 158 & 17.21 & 1360 \\
\hline 79 & 12 & 1192 & -9.4 & 58 & 1.13 & 350 & 1.41 & 1729 & 4.03 & 179 & 17.94 & 406 \\
\hline 80 & 12 & 1192 & -9.4 & 58 & 1.26 & 260 & 1.48 & 1845 & 3.90 & 174 & 17.03 & 226 \\
\hline 81 & 12 & 1192 & -9.4 & 58 & 1.39 & 186 & 1.21 & 1916 & 4.00 & 166 & 17.81 & 105 \\
\hline 82 & 12 & 1192 & -9.4 & 58 & 1.09 & 259 & 1.51 & 1702 & 3.91 & 18627 & 16.82 & 89 \\
\hline 83 & 12 & 1192 & -9.4 & 58 & 1.02 & 237 & 1.38 & 1874 & 3.78 & 5388 & 17.75 & 104 \\
\hline 84 & 12 & 1192 & -9.4 & 58 & 1.40 & 241 & 1.42 & 1820 & 3.80 & 1672 & 16.91 & 106 \\
\hline 85 & 12 & 1183 & -8.8 & 42 & 0.91 & 352 & 1.27 & 1697 & 4.00 & 152 & 16.72 & 370 \\
\hline 86 & 12 & 1183 & -8.8 & 42 & 1.03 & 340 & 1.35 & 1573 & 3.86 & 6152 & 15.93 & 160 \\
\hline 872 & 12 & 1168 & -8.9 & 17 & - & - & 1.16 & 1863 & 3.10 & 139 & 12.43 & 262 \\
\hline $88^{2}$ & 12 & 1168 & -8.9 & 17 & 1.01 & 271 & 1.18 & 1728 & 3.60 & 6725 & 12.62 & 284 \\
\hline 89 & 12 & 1162 & -9.1 & 25 & 1.15 & 252 & 1.53 & 1558 & 4.20 & 10256 & 18.90 & 120 \\
\hline 90 & 12 & 1162 & -9.1 & 25 & 1.26 & 329 & 1.42 & 1479 & 4.09 & 116 & 19.10 & 618 \\
\hline 91 & 12 & 1158 & -9.0 & 24 & 0.93 & 352 & 1.48 & 1748 & 4.24 & 100 & 18.56 & 280 \\
\hline 92 & 12 & 1155 & -8.5 & 48 & 0.77 & 160 & 1.47 & 1720 & 5.01 & 122 & 18.78 & 3620 \\
\hline
\end{tabular}

$\mathrm{D}_{\mathrm{Cr}}$ etc. - partition coefficient

2 not in equilibrium

- not determined

Comp. refers to the starting material composition in Table 1. 
In their study on the synthetic system forsterite-anorthite-silica, Schreiber and Haskin (1976) noted that chromium redox equilibrium is strongly dependent on temperature and oxygen fugacity. They also reported that $\mathrm{D}_{\mathrm{Cr}}$ increases with decreasing oxygen fugacity. A similar trend is demonstrated by the present data.

The partitioning values of chromium between olivine and liquid as a function of temperature are shown in Fig. 6 at fo $_{2}$ close to FMQ. Above about $1160{ }^{\circ} \mathrm{C}$ the values are greater than one, indicating that chromium prefers the olivine lattice. In terms of the crystal chemistry this means the substitution of chromium ion for iron and magnesium in the octahedral site. This will be discussed later. However, below $1160{ }^{\circ} \mathrm{C}$ olivine seems to repel chromium.

The experiments at constant oxygen fugacity show clearly that the partititon coefficient decreases with decreasing temperature. There is, however, no apparent change in olivine composition within a large temperature interval (Roeder and Emslie, 1970). This means that at lower temperatures olivine almost retains the high temperature composition that offers more octahedral sites for $\mathrm{Cr}$ than does low-temperature olivine. Especially $\mathrm{Cr}^{3+}$, which has the highest octahedral site preference energy of the elements studied, will be enriched relatively more than other elements.

To test this hypothesis the data of four natural samples are shown in Fig. 6. One of these has chromium spinel inclusions as described by Mäkipää (1978 a); all of them are slightly crystalline and the olivine crystals observed represent equilibrium (Mäkipää, 1978 b; Grönvold and Mäkipää, 1978).

The equilibrium temperatures for the natural samples were calculated using the partitioning of $\mathrm{MgO}$ (Roeder and Emslie, 1970); in melting experiments at 1-atm pressure the temperatures differed no more than about $5{ }^{\circ} \mathrm{C}$ from the calculated values. All these natural samples are remarkably consistent with the controlled (QMF) oxygen fugacity line.
Fig. 7. The partitioning of Mn between olivine and liquid as a function of temperature. W 0.29 etc. Watson (1977) with different $\mathrm{Si} / \mathrm{O}$ ratios. Solid lines 0.295 and 0.305 ( $\mathrm{Si} / \mathrm{O}$ ratio) were fitted to present data by method of least-squares.

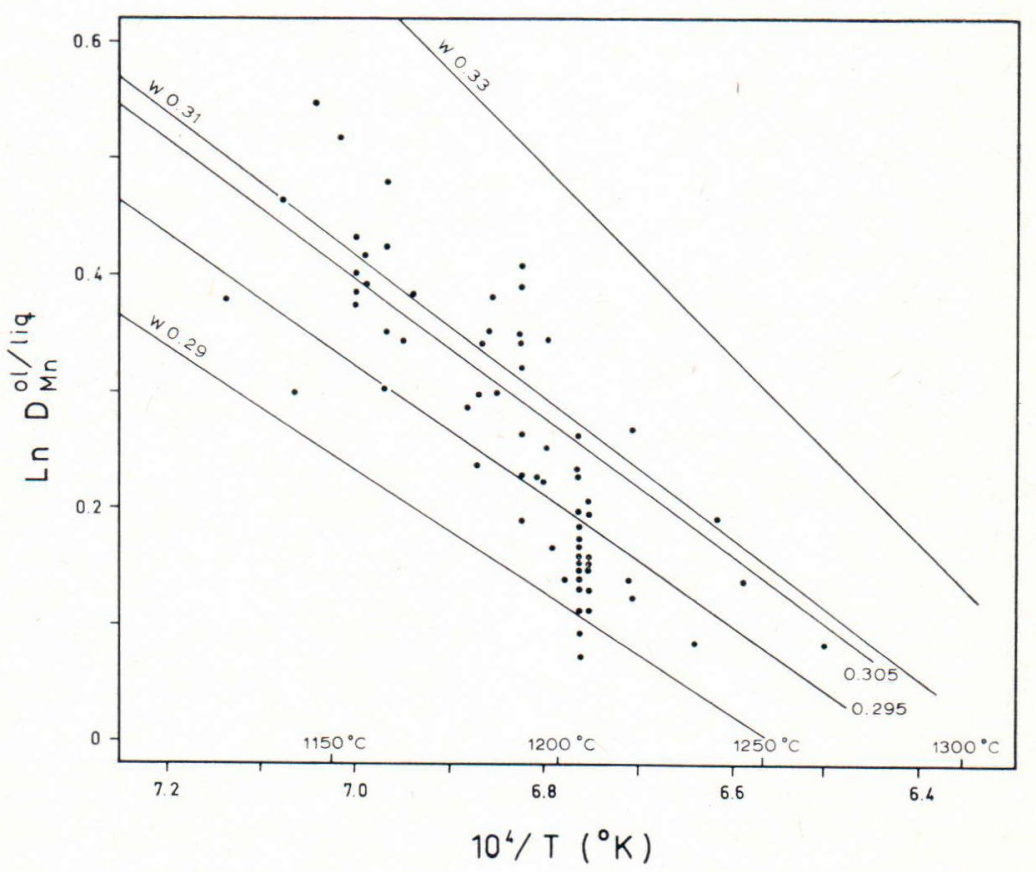


The only serious effect on partitioning is oxygen fugacity, which changes the composition of olivine and affects the amount of chromium in olivine. The strong correlation observed between $\mathrm{D}_{\mathrm{Cr}}$ and temperature is thus mainly due to the joint effect of buffered oxygen fugacity and temperature.

\section{M a n g a n e s e}

The control of the partition of manganese between olivine and liquid is complicated. Leeman (1974), Duke (1976) and Watson (1977) have determined experimentally the partition coefficients for $\mathrm{Mn}$ as a function of temperature. The data available for $D_{M n}$ show a relatively large scatter, mostly caused by the variation in magma composition.

As seen in Fig. 7, the main trend is for partition coefficients to increase with decreasing temperature. All the values in this temperature range $\left(1125-1250{ }^{\circ} \mathrm{C}\right)$ are greater than one indicating that $\mathrm{Mn}$ prefers the olivine lattice.

It is important to discriminate between the effects of $\mathrm{fo}_{2}$ and bulk composition on the partition coefficient. The experiments at constant oxygen fugacity show very clearly that $\mathrm{fo}_{2}$ markedly affects the partition coefficient. It is well known that at this oxygen fugacity manganese is always divalent. Probably the only way to explain this is by the relatively constant olivine composition, which as with $\mathrm{Cr}$, is conspicuously dependent on $\mathrm{fo}_{2}$. This problem was avoided by Watson (1977), who used iron-free compositions in his experiments. In the system with a persistent forsterite structure $\mathrm{fo}_{2}$ has no apparent effect.

The experiments at controlled $\mathrm{fo}_{2}$ show systematic variation in the partition coefficients in relation to temperature: the lower the temperature the higher the partition coefficient. The relatively large scatter in the plot is due to the difference in composition. Although the $\mathrm{FeO} /(\mathrm{FeO}+\mathrm{MgO})$ ratio only varies from about 0.51 to 0.73 and the $\mathrm{Si} / \mathrm{O}$ ratio from 0.290 to 0.311 , this narrow composition range has a considerable influence on partition coefficients.

On the basis of the present data, two Mn partition equations were calculated for different $\mathrm{Si} / \mathrm{O}$ ratios, one with a $\mathrm{Si} / \mathrm{O}$ ratio equal to 0.295 and the other equal to 0.305 , representing the range observed in the most common Icelandic tholeiites.

Watson (1977) has discussed the suitability of the $\mathrm{Si} / \mathrm{O}$ ratio in reflecting the melt composition. With his experimental results the following lines can be calculated for different $\mathrm{Si} / \mathrm{O}$ ratios: $\mathrm{Si} / \mathrm{O}=0.285,0.307$ and 0.320 . The consistency with Watson's data (Fig. 7) supports the validity of the $\mathrm{Si} / \mathrm{O}$ ratio as a general structural parameter, even though Watson (op.cit.) used iron-free materials.

The natural test samples follow these lines remarkably well, indicating the usefulness of this geothermometer when the compositional effect is taken into account.

\section{Cob a $1 t$}

The natural cobalt content of the rocks studied was very low, down to about $30 \mathrm{ppm}$. The amount of Co usually decreases rapidly with crystallization and Co mainly enters olivines and pyroxenes.

Assuming that the octahedral site preference energy is one of the most important factors controlling the partition of transition metals between olivine and liquid, the partitioning of Co should not be so sensitive to compositional differences as that of $\mathrm{Ni}$.

On this basis, behaviour of Co partitioning at constant oxygen fugacity is easily understood. Although under these conditions the structure of olivine offers more octahedral sites, Co, unlike $\mathrm{Cr}$, does not show any such preference.

All the experiments at constant $\mathrm{fo}_{2}$ and at buffered $\mathrm{fo}_{2}$ show a linear correlation be- 


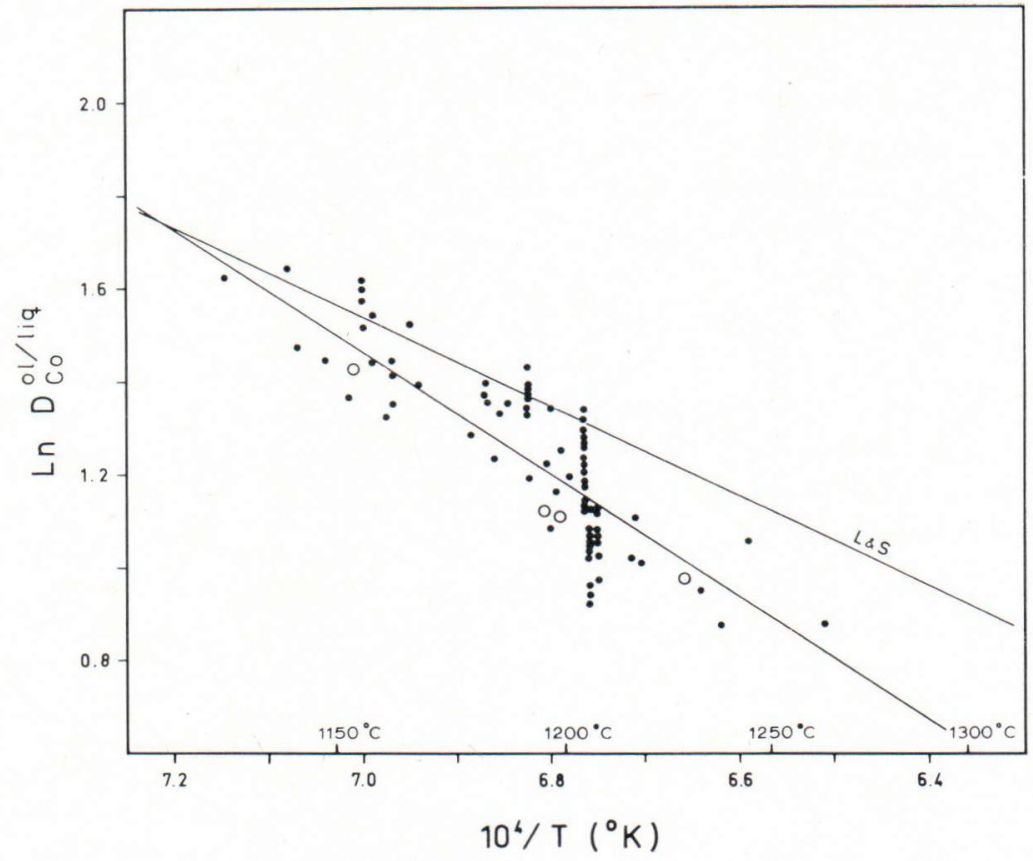

Fig. 8. The partitioning of Co between olivine and liquid as a function of temperature. L \& S - Leeman \& Scheidegger (1977), solid line (without index) was fitted to present data by method of least-squares, open circles - test samples (natural lava). tween partition coefficient and temperature (Fig. 8), the partition coefficient increasing with decreasing temperature. Owing to the rather good correlation the Co partition between olivine and liquid is readily applicable to natural rocks.

\section{$\mathrm{Nickel}$}

Since the classic paper by Häkli and Wright (1967) the partition coefficients for nickel have often been used as a geothermometer. On the basis of octahedral site preferency energy, Ni should show by far the strongest enrichment in olivine. Unfortunately this also means that the partitioning of $\mathrm{Ni}$ is strongly dependent on the composition of the melt, because in more silica-rich melt the degree of polymerization of $\mathrm{SiO}_{4}$ tetrahedras increases.

If the $\mathrm{Si} / \mathrm{O}$ ratio is related to the melt structure then the compositional dependence of the partitioning of $\mathrm{Ni}$ may be partially resolved. In the present experiments the $\mathrm{Si} / \mathrm{O}$ ratio varied from 0.29 to 0.31 and all the partition coefficients displayed a significant temperature dependence (Fig. 9). To distinguish between compositional effcet and temperature dependence some experimental results $(\mathrm{Si} / \mathrm{O}=0.27-0.37)$ by Hart and Davis (1978) are shown on the same diagram. For melts with $\mathrm{Si} / \mathrm{O}$ ratios of about 0.30 , the close agreement with the present experiments indicates that the composition dependence of the Ni-partition coefficient is very small over the range of melt compositions considered. Leeman's data (1974) with an $\mathrm{Si} / \mathrm{O}$ ratio 0.300 also plot very close to the line presented, which is a combination of data from Leeman and Lindstrom (1978) and Hart et al. (1976), with $\mathrm{Si} / \mathrm{O}$ close to 0.300 .

Hart and Davis (1978) suggested that $\mathrm{D}_{\mathrm{Ni}}$ varies inversely with the $\mathrm{MgO}$ content of liquid at a given temperature, even at a constant value of $\mathrm{Si} / \mathrm{O}$. The same was true in the present study. This NiO-MgO relationship possibly gives an exchange constant (Ni/Mg) olivine/(Ni/Mg) melt that is more convenient 
Fig. 9. The partitioning of $\mathrm{Ni}$ between olivine and liquid as a function of temperature. L \& L - Leeman \& Lindstrom (1978), H \& W Häkli \& Wright (1967), open circles - test samples (natural lava), triangles - Leeman (1974) $\mathrm{Si} / \mathrm{O}$ ratio 0.300 , crosses - Hart \& Davis (1978) with different $\mathrm{Si} / \mathrm{O}$ ratios.

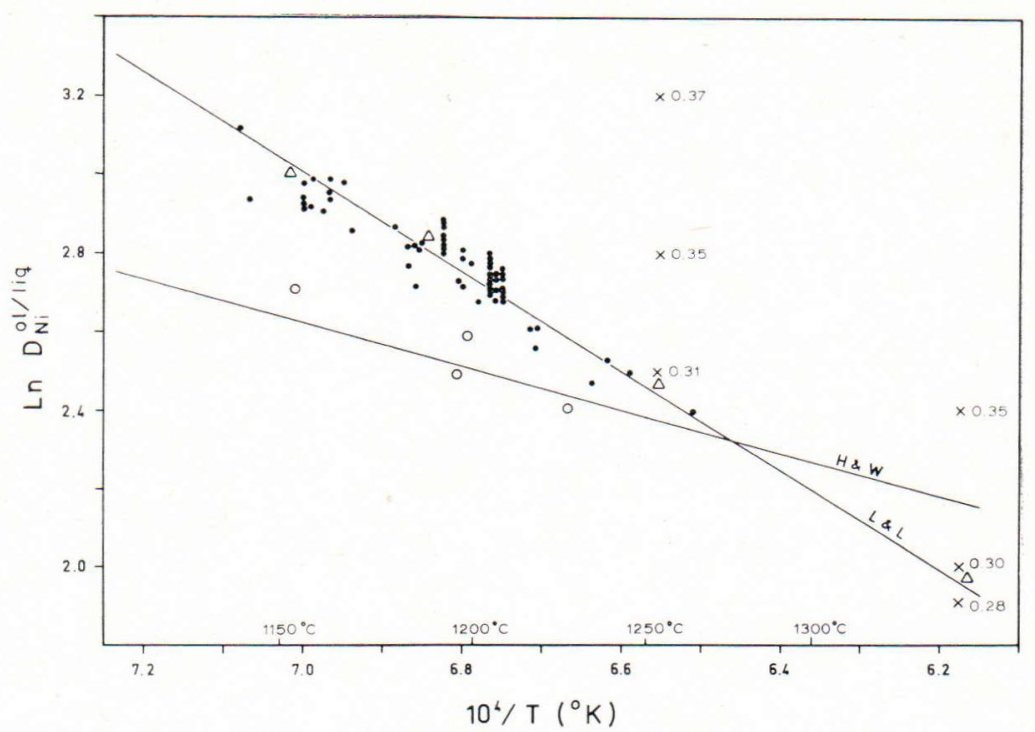

than the partition coefficient, but, as discussed by Hart and Davis (1978), the results do not agree as well with temperature as do the D values. For further discussion, see Leeman (1974) and Hart and Davis (1978).

As mentioned above, Häkli and Wright (1967) collected and studied five samples from the Makaopuhi lava lake in Hawaii and based their geothermometer on the fractionation of nickel between olivine and glass. The composition of the lava is rather similar to that used here.

Their data, however, show a smaller temperature dependence than that given here. This small but significant divergence might be due to inaccuracies in their sample collection (especially temperature determinations) or to the disequilibrium between olivine and liquid. Nonetheless, their data are well suited to natural samples under conditions that are difficult to duplicate in experimental laboratories. In fact all the natural test samples used here are consistent with the line presented by Häkli and Wright (1967) (Fig. 9).

Takahasi (1978) proposed $\mathrm{K}^{\mathrm{MgO}}=(\mathrm{MgO})^{\mathrm{ol} /}$ $(\mathrm{MgO})^{\text {liq }}$ (mole ratios) as a quantitative pa- rameter for comparing different liquid compositions. With this ratio as a parameter the precision of the geothermometer is not better (in some cases even poorer) than with the $\mathrm{Si} / \mathrm{O}$ ratio as a compositional parameter.

\section{Summary of experimental results}

The partition coefficients for transition metals in silicate melts are likely to be affected by various external and internal properties of the magma. In the present study natural rocks were used in the experiments in the attempt to evaluate the effects of some of these variables.

The concentration of the element in question does not affect the partition coefficients up to at least 1 wt. $\%$, i.e. all the elements studied obeyed Henry's law.

At these temperatures the partition coefficients (except for that of $\mathrm{Cr}$ ) are greater than one indicating that these elements prefer the olivine lattice and will thus be rapidly depleted from liquid during crystallization.

The strong temperature-dependence of the partition coefficients for $\mathrm{Cr}, \mathrm{Mn}, \mathrm{Co}$ and $\mathrm{Ni}$ has been used to calculate temperatures for 


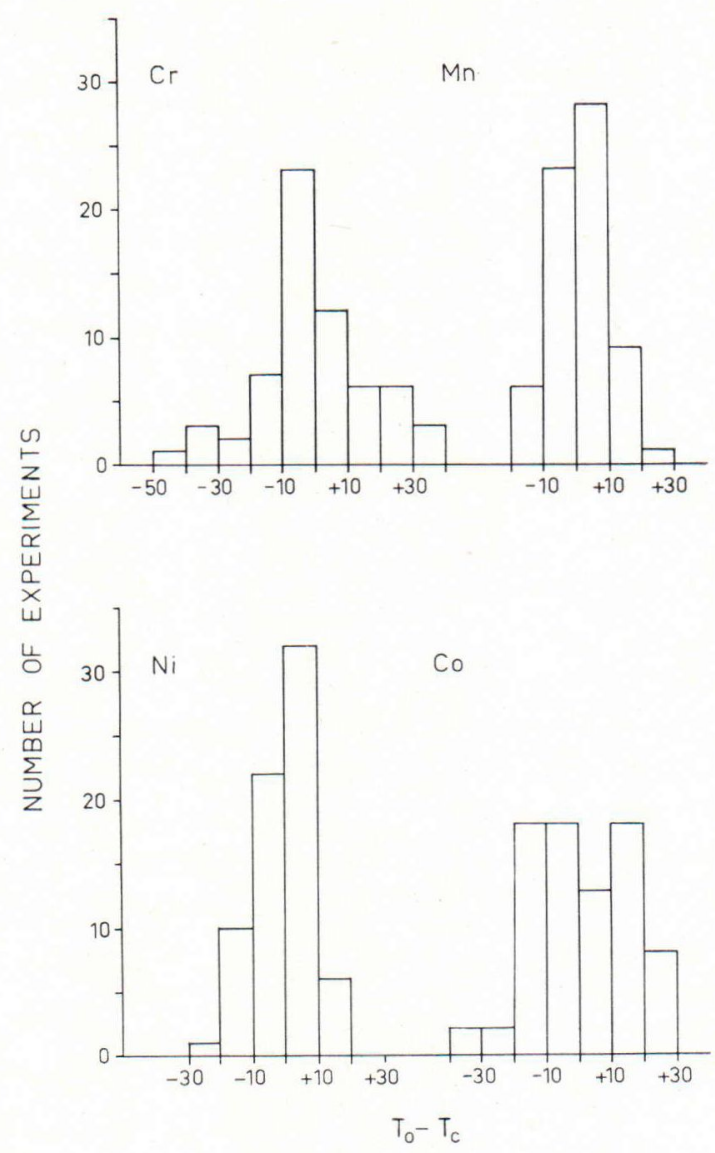

Fig. 10. The difference between the calculated $\left(\mathrm{T}_{\mathrm{c}}\right)$ and observed $\left(\mathrm{T}_{\mathrm{o}}\right)$ temperatures of present experiments.

the experimental data incorporated in the regression analyses. Fig. 10 shows the difference between the calculated $\left(\mathrm{T}_{\mathrm{c}}\right)$ and $\mathrm{ob}-$ served $\left(\mathrm{T}_{0}\right)$ temperatures for each element. The present data suggest that the precision of these geothermometers in terms of the relative temperatures is generally within $\pm 20{ }^{\circ} \mathrm{C}$ (see below).

The main results are briefly:

(1) $\mathrm{Cr}$. The partition coefficient between olivine and liquid is dependent on temperature and $\mathrm{fo}_{2}$. The $\mathrm{D}$ varies slightly with temperature but increases rapidly with decreasing oxygen fugacity. By combining these two features the tem- perature can be estimated reasonably to within about $\pm 30^{\circ} \mathrm{C}$.

(2) $M n$. The partition coefficient between olivine and liquid is strongly dependent on bulk composition. With the $\mathrm{Si} / \mathrm{O}$ ratio as an index of the liquid structure, a good correlation between $\mathrm{D}_{\mathrm{Mn}}$ and temperature is obtained at constant $\mathrm{Si} / \mathrm{O}$ ratio.

(3) Co. The partition coefficient for Co between olivine and liquid appears to be dependent on temperature alone. The variation in composition and $\mathrm{fo}_{2}$ has no apparent effect. Concentrations of $\mathrm{Co}$ could therefore be used as a geothermometer within a precision of about $\pm 20^{\circ} \mathrm{C}$ or better. More experimental data could improve the geothermometer still further.

(4) Ni. The partition coefficient for $\mathrm{Ni}$ is very strongly dependent on temperature, but at constant temperature the $\mathrm{D}$ is also strongly dependent on melt composition and varies inversely with the $\mathrm{MgO}$ content of the melt. For basaltic melts (Si/O ratio close to 0.30 ), however, the precision of this geothermometer is within $\pm 20^{\circ} \mathrm{C}$.

\section{Discussion and comparison with other studies}

The partition coefficients of $\mathrm{Cr}, \mathrm{Mn}$, Co and $\mathrm{Ni}$ between the olivine and liquid studied vary rather widely. To explain this behaviour, their dependence on the composition of the basaltic melts and the influence of the variation on the activity coefficients of the elements must be established.

Very little is known, however, about the structure of basaltic melts. It has been argued (Whittaker, 1967) that tetrahedral sites dominate in the liquid studied and the number of octahedral sites available for transition metals decreases with decreasing basicity of the melt. 
All transition metal ions enter both normal octahedral and tetrahedral sites. In addition, a number of defect sites occur in crystals and melt as a result of temperature and pressure history of crystallization. The transfer between the sites depends on various factors, e.g. the octahedral site preference energy (OSPE) of the element. In short, during crystallization the number of octahedral sites decreases and therefore the ions with strong OSPE enter the crystal lattice, which offers numerous octahedral sites, rather than become enriched in »more tetrahedral» liquid.

$\mathrm{Cr}^{3+}$ has the strongest OSPE (38 kcal) of the elements studied and therefore occurs in octahedral coordination. The $\mathrm{Cr}^{3+}$ ions show the greatest early enrichment in transition metals. Curtis (1964) reported that early fractionation in the Skaergaard intrusion had removed most of the $\mathrm{Cr}^{3+}$ from the magma. $\mathrm{Cr}^{3+}$, however, mainly enters the pyroxene lattice in excellent agreement with the present experiments, because $\mathrm{Cr}^{3+}$ seems to disfavour olivine at lower temperatures during crystallization. This is conspicuous when pyroxene starts to crystallize.

Because of its relatively strong OSPE (21 kcal), $\mathrm{Ni}^{2+}$ should be expected, on the basis of the crystal field theory, to show the strongest early enrichment of divalent transition metals. In fact this is easily seen if we compare the OSPE and partition coefficients of divalent cations (e.g. Henderson and Dale, 1970). Leeman and Scheidegger (1977) noted that the relation $\operatorname{lnD}$ vs. OSPE is not linear for all the elements (especially Co has a higher $D$ value) and argued that ionic size and OSPE are not the sole controls of partitioning. $\mathrm{Co}^{2+}$, however, has a very weak OSPE (7 kcal) and hence might be one of the most promising transition metals for partition studies; the weaker the OSPE the more independent the partition coefficient is of total composition.

The change in the partition behaviour of the transition metals studied might be largely influenced by the variation in the activity coefficients of $\mathrm{Cr}_{2} \mathrm{O}_{3}, \mathrm{MnO}, \mathrm{CoO}$ and $\mathrm{NiO}$ in the magma. Little is, however, known about their activities. Some approximations can be made for some major elements. The activity of the element is a function of temperature, oxygen fugacity and total composition. Roeder (1974) showed that the activity coefficient of iron in basaltic melts is a function of alkalies and alumina. Developing his model further, we can establish also the silica activity.

Leeman and Lindstrom (1978) described a method for estimating $\mathrm{NiO}$ activity in liquid and argued that the activity coefficient depends strongly on temperature but less on melt composition. Nonethelses, it should be pointed out that the activity coefficient of $\mathrm{NiO}$ is dependent on the concentration of $\mathrm{Ni}$ in liquid.

A more convenient method for approximating the activities is to use mole fractions. These approximations are clearly far from the true values, but until more thermodynamic data are available, they give the best results. Further, in the present study, there should not be any significant difference between the activities because of the small range in temperature and melt composition.

As mentioned earlier, the present experiments show clearly that Henry's law is valid for all the elements studied from natural levels (about $30 \mathrm{ppm}$ ) to about $1 \%$. However, much more experimental data are needed at higher pressures and in the presence of volatiles before the final word can be said.

Schreiber and Hanskin (1976) reported a highly significant dependence of $\mathrm{D}_{\mathrm{Cr}}$ on temperature at low fugacity $\left(\sim 10^{-9}\right)$; at higher fugacities $\left(\sim 10^{-3}\right)$, however, the effect is very weak. Akella (1975) investigated the partitioning of $\mathrm{Cr}$ between silicates and liquid at 1-atm pressure as a function of temperature, partial pressure of oxygen and cooling rate. In summarizing his results he noted that $\mathrm{D}_{\mathrm{Cr}}$ 
decreases as temperature decreases and that at constant temperature $\mathrm{D}_{\mathrm{Cr}}$ increases with decreasing oxygen fugacity.

The results of the present study are consistent with the studies cited above. If the effects of oxygen fugacity and temperature are combined, it is easy to understand the relatively high correlation observed between partition coefficient $\left(\mathrm{D}_{\mathrm{Cr}}\right)$ and temperature at buffered oxygen fugacity.

Duke (1976) studied experimentally the partitioning of some transition metals but some doubt has been cast on his results in the literature because of the converse apparent variation with temperature compared with the data of other workers. Lindstrom and Weill (1978) pointed out that the oxygen fugacity $\left(10^{-9.7}-10^{-10.4}\right)$ in Duke's experiments should cause the reverse but, as shown in this study, an oxygen fugacity of up to $10^{-9.5}$ has no such an effect.

In his study on manganese partitioning Watson (1977) maintained that the disagreements regarding Leeman's (1974) data are the result of differences in the thermodynamics of iron-bearing (Leeman) and iron-free (Watson) systems.

The present study, however, does not support this. If this were the case, then Duke's data should show apparent deviation as well. The agreement between Duke's and Watson's data is, however, adequate. In general, for temperature measurement applications, the

\section{References}

Akella, J. (1975) Partitioning of $\mathrm{Cr}$ between coexisting silicates, oxides, and liquids (abstract). EOS (Trans. Am. Geophys. Union) 56: 464.

Curtis, C. D. (1964) Applications of the crystalfield theory to the inclusion of trace transition elements in minerals during magmatic differentiation. Geochim. Cosmochim. Acta 28: 389-404.

Drake, M. J. (1972) The distribution of major agreement for Mn between the data of Leeman (1974), Duke (1976), Watson (1977) and the present study is adequate if the compositional effect is taken into account.

The overall close agreement between the present results and those of, say, Leeman (1974) and Leeman and Lindstrom (1978) for basalts warrants the use of transition metal partitioning as geothermometry. The experimental technique and the starting materials were rather similar to those used by Leeman \& Lindström. The fact that they had markedly wider compositional and temperature ranges gives a good basis for detailed studies such as the present one.

No attempt was made, however, in the present study to evaluate the possible effects of pressure and volatiles (e.g. $\mathrm{H}_{2} \mathrm{O}, \mathrm{CO}_{2}, \mathrm{~F}$, $\mathrm{Cl}$ ) on the partition coefficients. Pressure might have a tendency to change the structural coordination of melt and to increase the solubility of divalent cations but this has not yet been established.

Acknowledgements - This study was carried out during my fellowship at the Nordic Volcanological Institute, Reykjavik Iceland. The final work on this paper was carried out while I was employed as a research assistant of the Natural Science Research Council of the Academy of Finland. Drs. Karl Grönvold and Aulis Häkli kindly read the manuscript and made a number of corrections and useful improvements. Mrs. Anni Vuori assisted with the drawnings. To all these persons I wish to express my deep gratitude.

and trace elements between plagioclase feldspar and magmatic silicate liquid: an experimental study. Ph.D. Dissertation, University of Oregon, Eugene, Ore.

Duke, J. M. (1976) Distribution of the period four transition elements among olivine, calcic clinopyroxene and mafic silicate liquid: experimental results. J. Petrol. 17: 499-521.

Green, D. H. and Ringwood, A. E. (1967) The 
genesis of basaltic magmas, Contr. Mineral. and Petrol. 15: 103-190.

Grönvold, K. and Mäkipää, H. (1978) Chemical composition of Krafla lavas 1975-1977. Nordic Volcanological Institute $78-16$.

Häkli, A. (1963) Distribution of nickel between the silicate and sulphide phases in some basic intrusions in Finland. Bull. Comm. Géol. Finlande 209. $54 \mathrm{pp}$.

- and Wright, T. L. (1967) The fractionation of nickel between olivine and augite as a geothermometer. Geochim. Cosmochim. Acta 31: $877-884$.

Hart, S. R., Davis, K. E., Watson, E. B. and Kushiro, I. (1976) Partitioning of nickel between olivine and silicate liquid. Geol. Soc. Amer. Ann. Mtg. Abst., 906.

- and Davis, K. E. (1978) Nickel partitioning between olivine and silicate melt. Earth and Plan. Sci. Letters 40: 203-219.

Henderson, P. and Dale, I. M. (1970) The partitioning of selected transition element ions between olivine and groundmass of oceanic basalts. Chem. Geol. 5: 267-274.

Huebner, J. S. and Lipin, B. R. (1976) Chromium partitioning between silicate melt and crystals: Experiments and application (abstract). In Lunar Science VII: 399-401. The Lunar Science Institute, Houston.

Johannes, W. and Bode, B. (1978) Loss of iron to the Pt-container in melting experiments with basalts and a method to reduce it. Contr. Mineral. and Petrol. 67: 221-235.

Leeman, W. P. (1974) Experimental determination of partitioning of divalent cations between olivine and basaltic liquid. Ph.D. Thesis, University of Oregon, Part II, pp. 231-303.

- and Lindström, D. J. (1978) Partitioning of $\mathrm{Ni}^{+}+$between basaltic and synthetic melts and olivine: an experimental study. Geochim. Cosmochim. Acta 42: 801-817.

- and Scheidegger, K. F. (1977) Olivine/liquid distribution coefficients and a test for crystalliquid equilibrius. Earth and Plan. Sci. Letters 35: $247-257$.

Lindström, D. J. and Weill, D. F. (1978) Partitioning of transition metals between diopside and coexisting silicate liquids. I. Nickel, kobalt and manganese. Geochim. Cosmochim. Acta 42: $817-832$.

Mäkipää, H. T. (1978 a) Petrological relations in some Icelandic basaltic hyaloclastites. Bull. Geol. Soc. Finland 50: 81-112.

- (1978 b) Mineral equilibria, geothermometers and geobarometers in some Icelandic hyaloclastites. Bull. Geol. Soc. Finland 50: 113-134.

- (1979) Contribution to the $\mathrm{Fe}_{2} \mathrm{O}_{3} / \mathrm{FeO}$ determination in basaltic rocks. Bull. Geol. Soc. Finland 51: $125-129$.

Mysen, B. (1978) Limits of solution of trace elements in minerals according to Henry's law: Review of experimental data. Geochim. Cosmochim. Acta 42: 871-885.

- Arculus, R. S. and Eggler, D. H. (1975) Solubility of carbon dioxide in melts of andesite, tholeiite, and olivine nephelinite compositions to $30 \mathrm{~kb}$ pressure. Contr. Mineral. and Petrol. 53: 227-239.

Roeder, P. L. (1974) Activity of iron and olivine solubility in basaltic liquids. Earth and Plan. Sci. Letters 24: 397-410.

- and Emslie, R. F. (1970) Olivine-liquid equilibrium. Contr. Mineral. and Petrol. 29: 275289.

Schreiber, H. D. and Haskin, L. A. (1976) Chromium in basalts: experimental determination of redox states and partitioning among synthetic silicate phases. Proc. Seventh Lunar Sci. Conf., pp. 1221-1259.

Takahasi, E. (1978) Partitioning of $\mathrm{Ni}^{2+}, \mathrm{Co}^{2+}$, $\mathrm{Fe}^{2+}, \mathrm{Mn}^{2+}$ and $\mathrm{Mg}^{2+}$ between olivine and silicate melts: compositional dependence of partition coefficient. Geochim. Cosmochim. Acta 42: 1829-1843.

Watson, B. E. (1977) Partitioning of manganese between forsterite and silicate liquid. Geochim. Cosmochim. Acta 41: 1363-1374.

Whittaker, E. J. W. (1967) Factors affecting element ratios in the crystallization of minerals. Geochim. Cosmochim. Acta 31: 2275-2288.

Wones, D. R. and Gilbert, C. M. (1969) The fayalite-magnetite-quartz assemblage between $600^{\circ}$ and $800^{\circ}$ C. Am. J. Sci., Schairer Vol. 267-A: $480-488$.

Manuscript received, February 15, 1980 